\title{
РОЛЬ ЦІННІСНО-МОТИВАЦІЙНОЇ СФЕРИ ОСОБИСТОСТІ В ПРОЦЕСІ АДАПТАЦЇ̈ УКРАЇНСЬКИХ ЗИМІВНИКІВ ДО ЖИТТЕДІЯЛЬНОСТІ В УМОВАХ АНТАРКТИКИ
}

\author{
Олена Мірошниченко \\ кандидат педагогічних наук, доцент, доцент кафедри педагогіки, \\ професійної освіти та управління освітніми закладами \\ Житомирський державний університет імені Івана Франка \\ 10002, Україна, м. Житомир, вул. Велика Бердичівська, 40 \\ perspektiva-z@ukr.net, http://orcid.org/0000-0002-5712-3752
}

\begin{abstract}
Анотація
Статтю присвячено дослідженню ролі ціннісно-мотиваційної сфери особистості українських зимівників в процесі адаптації до життєдіяльності на Українській антарктичній станції «Академік Вернадський». Актуальність обраної теми грунтується на тому факті, що Україна є однією з 19 країн світу, що мають на шостому континенті, Антарктиді, постійно діючі антарктичні станції. Члени Українських антарктичних експедицій виконують наукові дослідження 3 таких галузей наук, як біологія, гідрометеорологія, геофізика, геологія, інженерія, психологія, психофізіологія. Зимівникам доводиться працювати в екстремальних умовах, які пов'язано з впливом на людину низьких температур, зсуву часових і світлових поясів, сенсорної депривації, психологічних особливостей роботи і відпочинку в обмеженому колективі тощо. Метою статті $є$ теоретичне обгрунтування та емпіричне доведення ролі ціннісно-мотиваційної сфери особистості в процесі адаптації українських зимівників до життєдіяльності в умовах Антарктики.

Проаналізовано наукові розробки вітчизняних і зарубіжних дослідників, що займаються проблемою адаптації до життєдіяльності в екстремальних умовах. Уточнено поняття адаптації та адаптивності до екстремальних умов; обгрунтовано та описано методологічний інструментарій дослідження. Проведено емпіричне дослідження щодо виокремлення груп високої, середньої та низької адаптивності до життєдіяльності в екстремальних умовах Антарктики; визначено критерії для виділення груп різного рівня адаптивності: кількість зимівель, соціометричний рейтинг, наявність якостей особистості, необхідних для життєдіяльності в екстремальних умовах. Визначено роль ціннісно-мотиваційної сфери у представників кожної групи. Доведено, що в зимівників високого рівня адаптивності переважають професійні цінності; у зимівників середнього та низького рівнів адаптивності пізнавальні цінності; також для зимівників низького рівня адаптивності велику роль мають цінності матеріального характеру.
\end{abstract}

Ключові слова: адаптація, адаптивність, цінності особистості, групи високої, середньої та низької адаптивності, особистість, життєдіяльність, ціннісно-мотиваційна сфера.

\section{Ветуп}

До 1991 р. українські вчені досліджували шостий континент у складі радянських експедицій. Після набуття незалежності, Україна приєдналася до міжнародного «Договору про Антарктиду», а в 1996 р. підняла в Антарктиді Український прапор над станцією 
«Академік Вернадський». Актуальність обраної теми грунтується на тому факті, що Україна є однією з 19 країн світу, що мають на шостому континенті, Антарктиді, постійно діючі антарктичні станції. Члени Українських антарктичних експедицій виконують наукові дослідження з таких галузей наук, як біологія, гідрометеорологія, геофізика, геологія, інженерія, психологія, психофізіологія.

Для науковців країни проводити наукові дослідження не лише почесно, а й дуже відповідально, адже високоширотні зони планети $\epsilon$ своєрідним дзеркалом, у якому відбиваються всі процеси змін на Землі. Така вагома міжнародна місія ставить перед науковцями України важливі завдання. Від рівня підготовки фахівців, що виконують професійну діяльність в умовах Антарктики, залежить майбутнє як розвитку вітчизняної науки, так i міжнародного співробітництва. Зимівникам доводиться працювати в екстремальних умовах, пов'язаних з впливом на людину низьких температур, зсуву часових $\mathrm{i}$ світлових поясів, сенсорної депривації, психологічних особливостей роботи і відпочинку в обмеженому колективі тощо.

Дослідження проблеми адаптації до умов перебування в Антарктиці проводяться в різних аспектах як вітчизняними, так і зарубіжними науковцями. Так, С. Моісеєнко та його колеги, фізіологи, вивчали фізіологічні та психофізіологічні особливості адаптації зимівників (Moiseyenko, Sukhorukov, Pyshnov, Mankovska, Rozova, Miroshnichenko et al., 2016). Науковці зіставили результати обстеження до та після експедицій, виявили наявність психофізіологічних змін у зимівників, що відповідають за психоемоційний стан людини. Дослідники помічають суттєве зростання в останні роки випадків психофізіологічних i психологічних порушень зимівників під час перебування на антарктичній станції, незважаючи на психофізіологічний відбір кандидатів до участі в експедиціях (Моісеєнко, Мірошниченко, Мадяр, Розова, Кузовик, Ковалевська та ін., 2019).

Г. Пишнов досліджує питання стресостійкості осіб, що працюють в екстремальних умовах, зимівників, зокрема. Науковець встановив, що в учасників українських антарктичних експедицій, так само, як у представників таких професій, як авіадиспетчери, інженери-електронники, пожежні, спостерігається закономірність трансформації хронічного стомлення залежно від рівня напруженості праці (Пишнов, 2011). Ним розроблено підходи для визначення рівня вигоряння та його попередження з урахуванням різних механізмів розвитку хронічного стомлення фахівців.

А. Гордєєв займається розробкою інформаційних технологій професійного відбору зимівників 3 урахуванням психофізіологічного стану організму (Гордєєв, 2016). Для проведення професійного відбору автором розроблено комп’ютерну програмну систему та накопичено спеціалізовану базу даних. Розроблену технологію експериментально реалізовано на базі кафедри біокібернетики та аерокосмічної медицини Національного авіаційного університету (м. Київ).

Л. Бахмутова вивчає психологічні особливості взаємодії членів українських експедицій в умовах замкнутого колективу (Bakhmutova, 2019). Авторкою виділено три сфери спілкування зимівників під час зимівлі (професійна, особистісна, проведення дозвілля) та надані психологічні рекомендації щодо оптимізації міжособистісних стосунків в обмеженому колективі.

M. Mehta, G. Chugh досліджують психологічний аспект мотивації до діяльності зимівників індійських антарктичних станцій (Mehta \& Chugh, 2011). Автори встановили, що важливу роль в адаптації до екстремальних умов відіграють соціальні риси особистості, такі, 
як ентузіазм, відповідальність, оптимістична орієнтація на майбутнє, витримка, рішучість та підтримка товаришів.

Наші дослідження стосуються вікових аспектів адаптації, індивідуально-типологічних особливостей і складових готовності українських зимівників до життєдіяльності в умовах Антарктики, їх результати висвітлені у попередніх публікаціях (Мірошниченко, 2016; Мірошниченко, Гуцуляк \& Марченко, 2018; Мірошниченко \& Пасічник, 2020).

Мета дослідження: теоретично обгрунтувати та емпірично довести роль ціннісномотиваційної сфери особистості в процесі адаптації українських зимівників до життєдіяльності в умовах Антарктики. Завдання дослідження: 1) проаналізувати наукові праці 3 проблеми дослідження; 2) уточнити поняття «адаптація» й «адаптивність»; 3) обгрунтувати й описати методологічний інструментарій дослідження; 4) провести емпіричне дослідження щодо виокремлення груп високої, середньої та низької адаптивності до життєдіяльності в екстремальних умовах Антарктики та визначити роль ціннісномотиваційної сфери у представників кожної групи.

\section{Методи дослідження}

Емпіричне дослідження проводилося в період з 2011 року по 2020 рік. В дослідженні взяли участь члени Українських антарктичних експедицій, що виконували професійні обов'язки на станції «Академік Вернадський» впродовж 12-13-ти місяців поспіль. Загальна кількість досліджуваних - 71, з них 69 осіб чоловічої статі, 2 - жіночої; їхній вік - від 23-х до 63-х років.

Організація досліджень узгоджується з програмою технічних і психологічних завдань Національного антарктичного наукового центру (НАНЦ) України перед початком чергової Української антарктичної експедиції, яка розпочинається навесні щороку.

Для визначення ролі ціннісно-мотиваційної сфери особистості в процесі адаптації українських зимівників до умов життєдіяльності в Антарктиці ми спиралися на теоретичні положення, які розкрито в працях вітчизняних і зарубіжних класиків психології Б. Ганнушкіна, А. Маслоу, Р. Нємова, А. Петровського, К. Платонова, К. Роджерса, Ю. Трофімова та ін.

Для встановлення соціометричного статусу членів експедицій було застосовано метод соціометричних вимірів Дж. Морено в нашій модифікації: соціометричні вподобання вимірювалися у трьох сферах - праця, особисті стосунки, проведення дозвілля. 3 метою визначення рейтингу особистісних якостей характеру у зимівників різного віку ми розробили для експертної групи анкету. Розподіл досліджуваних за рівнями адаптивності здійснювався за методикою розподілу ознак психологічних явищ (Сидоренко, 2007).

Для визначення ціннісно-мотиваційної сфери особистості зимівників застосовувалася методика «Ціннісні орієнтації» М. Рокіча (Райгородский, 2008: 637-641). Зокрема використовувалася перша частина методики - список А (термінальні цінності). Назви цінностей були надруковані на окремих карточках, i зимівникам пропонувалось розкласти їх за порядком значущості, як принципів, якими людина керується в житті. Кінцевий розклад карток має презентувати реальну позицію особистості щодо ціннісних орієнтацій.

3 групи методів обробки даних було використано кількісний аналіз: математична статистика; порівняння середніх значень за допомогою параметричних і непараметричних методів. Також застосовувався якісний аналіз отриманих даних: диференціювання матеріалу 
за типами досліджуваних. 3 групи інтерпретаційних методів використовувалася структурна та якісна інтерпретація особливостей результатів.

\section{Результати та дискусії}

Оскільки поняття адаптації та адаптивності є одними з основних у нашому дослідженні, то зупинимося на них детальніше. Адаптацію ми розглядаємо як процес пристосування особистості до умов, що змінюються, у нашому випадку, до екстремальних умов Антарктики. Людині доводиться пристосовуватися, як на рівні фізіологічних механізмів організму (холод, сенсорна депривація, метео-кліматичні ускладнення, магнітні впливи), так i на рівні психологічних процесів («відірваність» від домівки і близьких, необхідність спілкуватися 3 обмеженим колом членів експедиції, психоемоційні перевантаження під час несення добових вахт тощо).

Близьким до нашого є погляд на поняття адаптації А. Налчаджяна (Налчаджян, 2010). Науковець вважає, що процес адаптації є складним і багаторівневим явищем пристосування особи, як у мікросередовище, так і в макросередовище життєдіяльності. Автор стверджує, що добре адаптована людина $є$ такою, в якої не порушено рівновагу між продуктивністю праці, здатністю насолоджуватися життям і психічні процеси.

Що стосується поняття адаптивності, вважаємо, що це природна (на фізіологічному рівні) і набута (на психологічному рівні) здатність людини до адаптації, тобто пристосування різноманітних проявів життя за змінених умов. Важливий внесок у розробку поняття адаптивності здійснив Ж. Піаже (Фресс \& Пиаже, 1975). Він розглянув процес адаптації, як у біології, так і в психології, як єдність протилежно спрямованих процесів акомодації та асиміляції. Акомодацією психолог вважає адаптацію до середовища, що забезпечує функціонування організму згідно з умовами навколишнього середовища; а асиміляцією такий процес, що трансформує самі компоненти середовища, змінюючи їх, відповідно до потреб організму. Ці процеси тісно пов'язані між собою та опосередковують один одного, проте в кожному конкретному випадку один з них грає провідну роль.

Н. Даниленко, слідом за В. Гарбузовим, відносить до адаптаційних можливостей інстинкти людини, іiі темперамент, конституцію, емоції, рівень природжених властивостей інтелекту, спеціальні здібності, зовнішні дані і фізичний стан організму (Даниленко, 2019). Якщо людина має високий рівень адаптивності, то це означає, що вона володіє хорошими психофізичними даними, має високу працездатність, витривалість, стресотолерантність, психічну й фізичну гармонійність, гармонійність природжених і сформованих за життя особистісних якостей. Автори вважають, що рівень адаптивності людини може підвищуватися чи знижуватися під впливом виховання, навчання, умов і способу життя.

А. Маклаков, як суттєвий компонент адаптаційних можливостей, виділяє поняття особистісного адаптаційного потенціалу - рівень розвитку психологічних характеристик, що зумовлюють величину діапазону факторів середовища, до яких треба пристосуватися (Маклаков, 2017).

Е. Ларссен доводить, що здійснення задуманої мрії відбувається у тому випадку, якщо людина вміє працювати в екстремальних умовах, навіть на межі власних можливостей (Ларссен, 2016). Автор розробив методику, щоб стати сильніше та витриваліше для життєдіяльності в екстремальних умовах, і дав таким тренуванням назву «пекельний тиждень». Вони використовуються в Норвегії для підготовки десантників і спортсменів екстремальних видів спорту. Висновок після застосування цієї методики такий: успіху, а, 
отже, й адаптації до екстремальних умов життєдіяльності досягає така особистість, що має високу професійну мотивацію і велику кількість тренувань. Це цілком може стосуватися і зимівників Українських антарктичних експедицій.

Ми вважаємо, що адаптація, зокрема в екстремальних умовах, може бути більш ефективною, якщо у фахівця є позитивна мотивація до діяльності. Також рівень адаптивності людини може підвищуватися через ії особистісні орієнтації, систему цінностей, цілей і потреб тощо.

Для того, щоб визначити цінності зимівників, ми провели анкетування з групою, яка складала представників 2-х експедицій і сезонного загону зимівників (всього 36 осіб). Вони визначили та оцінили за 10-бальною системою 20 актуальних цінностей власного життя, за якими нами був побудований рейтинг цінностей і порівняння його 3 термінальними цінностями, визначеними М. Рокічем (Райгородский, 2008: 637-641). Це порівняння і рейтинг подано в табл. 1.

Табличя 1

Порівняння цінностей за методикою М. Рокіча та визначенням зимівників

\begin{tabular}{|c|c|c|c|}
\hline Цінності за М. Рокічем & $\begin{array}{c}\text { Цінності за визначенням } \\
\text { зимівників }\end{array}$ & $\begin{array}{l}\text { Отримані } \\
\text { бали }\end{array}$ & $\begin{array}{l}\text { Рейтинг } \\
\text { цінностей }\end{array}$ \\
\hline $\begin{array}{l}\text { Активне діяльне життя (повнота та } \\
\text { емоційно насичене життя) }\end{array}$ & $\begin{array}{l}\text { Колективізм } \\
\text { Авантюризм }\end{array}$ & $\begin{array}{c}139 \\
15\end{array}$ & $\begin{array}{c}2 \\
19\end{array}$ \\
\hline $\begin{array}{l}\text { Життєва мудрість (зрілість суджень, } \\
\text { життєвий досвід) }\end{array}$ & $\begin{array}{l}\text { Розум } \\
\text { Доброта }\end{array}$ & $\begin{array}{l}24 \\
40\end{array}$ & $\begin{array}{l}14 \\
12\end{array}$ \\
\hline Здоров’я (фізичне і психічне) & Здоров’я & 126 & 3 \\
\hline Цікава робота & Цікава робота & 48 & 9 \\
\hline \multicolumn{4}{|l|}{ Краса природи і мистецтва } \\
\hline $\begin{array}{l}\text { Кохання (духовна і фізична близькість } \\
3 \text { коханою людиною) }\end{array}$ & Кохання & 20 & 16 \\
\hline $\begin{array}{l}\text { Матеріально забезпечене життя } \\
\text { (відсутність матеріальних ускладнень) }\end{array}$ & $\begin{array}{l}\text { Добробут, } \text { матеріальна } \\
\text { винагорода }\end{array}$ & 61 & 7 \\
\hline Наявність хороших і вірних друзів & Дружба & 99 & 4 \\
\hline $\begin{array}{l}\text { Суспільне } \quad \text { визнання } \quad \text { (повага } \\
\text { колективі, товаришів по роботі) }\end{array}$ & $\begin{array}{l}\text { Повага } \\
\text { Порядність }\end{array}$ & $\begin{array}{l}24 \\
60\end{array}$ & $\begin{array}{c}14 \\
8\end{array}$ \\
\hline $\begin{array}{lrr}\text { Пізнання } & \text { (можливість } & \text { освіти, } \\
\text { розширення } & \text { світогляду, } \\
\text { iнтелектуальний розвиток) } & \end{array}$ & Пізнання & 18 & 18 \\
\hline 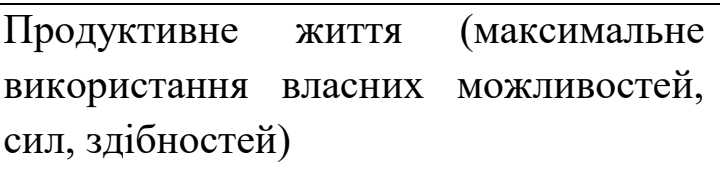 & $\begin{array}{l}\text { Бути майстром своєї } \\
\text { справи }\end{array}$ & 24 & 14 \\
\hline \multicolumn{4}{|l|}{$\begin{array}{l}\text { Розвиток (робота над собою, фізичне і } \\
\text { духовне вдосконалення) }\end{array}$} \\
\hline $\begin{array}{l}\text { Дозвілля (приємне проведення часу, } \\
\text { відсутність обов'язків) }\end{array}$ & Відпочинок & 13 & 20 \\
\hline $\begin{array}{l}\text { Свобода (самостійність, незалежність } \\
\text { в судженнях і вчинках) }\end{array}$ & Свобода & 84 & 6 \\
\hline Щасливе сімейне життя & Сім'я & 145 & 1 \\
\hline
\end{tabular}




\begin{tabular}{|l|l|c|c|}
\hline $\begin{array}{l}\text { Щастя інших (добробут, розвиток і } \\
\text { вдосконалення інших людей, всього } \\
\text { людства загалом) }\end{array}$ & $\begin{array}{l}\text { Пуманізм } \\
\text { Патріозм }\end{array}$ & 42 & 11 \\
\hline $\begin{array}{l}\text { Творчість (можливість творчої } \\
\text { діяльності) }\end{array}$ & Наявність мрії & 19 & 17 \\
\hline $\begin{array}{l}\text { Впевненість у собі (внутрішня } \\
\text { гармонія, свобода від суперечностей, } \\
\text { сумнівів) }\end{array}$ & Справедливість & 44 & 10 \\
\hline
\end{tabular}

Як видно з табл. 1, проаналізувавши рейтинг цінностей зимівників, найважливішими для них є: щасливе сімейне життя, колективізм, здоров'я, а найменш значущими - пізнання, авантюризм і відпочинок. Також великої уваги надається таким соціальним цінностям, як чесність, дружба та свобода.

Для визначення того, як наявність окремих цінностей впливає на адаптивність, ми провели з зимівниками (всього 71 осіб) дослідження за допомогою методики М. Рокіча «Ціннісні орієнтації», а результати ii проведення порівняли 3 віднесенням зимівників до різних груп адаптивності: високої, середньої та низької. Критеріями для виокремлення груп стали такі показники успішності адаптації до життєдіяльності в екстремальних умовах: 1) кількість зимівель; 2) соціальний статус члена експедиції; 3) якості особистості.

Щодо кількості зимівель, то вважаємо їх показниками того, чи адаптувалася людина до екстремальних умов, чи здаються вони прийнятними, чи повертається член експедиції знов до них. Щодо соціального статусу, вважаємо, що чим він вищий, тим краще член експедиції пристосувався до колективу, до особливостей ставлень у соціально, психологічно та природно екстремальних умовах. Третій показник ми довірили визначити експертній групі, до складу якої ввійшли керівник і досвідчений науковий співробітник відділу медикопсихологічного відділу Національного антарктичного наукового центру, та начальники українських експедицій за 10 досліджуваних нами років. Всього до експертної групи ввійшли 17 осіб.

Щоб об’єктивно зробити характеристику якостей особистості, необхідних для життєдіяльності в умовах Антартктики, ми провели попереднє анкетування з трьома групами зимівників (загальна кількість 36 осіб), які зимували в різні роки за досліджуваний період. Вони відповідали на питання: «Назвіть до 10 якостей особистості, які є найбільш важливими, на вашу думку, для зимівника, якій працює протягом року на Українській антарктичній станції?». Загалом зимівники назвали 42 якості, які були об'єднані в синонімічні «сім'і»». Так ми визначили 25 якостей, які, на думку самих зимівників, є необхідними для життєдіяльності в умовах Антарктики.

Вони подані в порядку зменшення необхідності: чесність; колективізм; товариськість; креативність, кмітливість; відповідальність; доброзичливість; стриманість, врівноваженість; працелюбність; людяність, гуманізм; толерантність, терпимість; життєрадісність, почуття гумору; щирість, відкритість; розумність, ерудованість; сила волі, наполегливість; активність, енергійність; спортивність, фізична сила і витривалість; порядність, справедливість; вірність, надійність; професіоналізм; сміливість; комунікабельність; артистизм, музичні здібності; патріотизм; дисциплінованість; мрійливість; скромність. 
Заслуговує на увагу той факт, що на перші місця потрапили якості, які є необхідними для спілкування в умовно замкненому колективі: чесність, колективізм і товариськість; велику роль у співпраці в екстремальних умовах відіграють такі якості особистості, як креативність і кмітливість; також зимівники надають значення відповідальності й доброзичливості у стосунках на антарктичній станції. Ці риси особистості названі зимівниками у першій п’ятірці якостей.

Відібраним експертам пропонувалось заповнити анонімно анкети, в яких, за абеткою, були подані перші десять найважливіших якостей особистості та прізвища досліджуваних зимівників. Експертам надавалась така інструкція, в якій пропонувалось дати відповідь на питання: «Які якості, на Вашу думку, має кожен український зимівник із пропонованого списку, якого Ви знаєте?». При цьому, якості, які виражено яскраво, потрібно було позначити цифрою 3, виражені середньо - 2, виражені слабко - 1, не виражені - 0. Анкета проводилася анонімно.

Оскільки рейтинг щодо кількості зимівель, рейтинг соціального ставлення та рейтинг якостей зимівників вимірювався в різних одиницях, то ми привели їх до єдиного вимірювання - 12 балів. Це найвищий бал у соціальному рейтингу (найбільший соціальний вибір у групі з 12-ти зимівників). Далі звели всі три показники разом, підрахувавши середній бал у кожного зимівника.

Середній бал за показниками середнього загального рейтингу, складає 6,1 балів, що майже збігається з медіаною ряду цифр нашого рейтингового списку. Вона дорівнює 6,0. Для виокремлення груп з високою, середньою та низькою адаптивністю ми використовували принцип розподілу вибірки на групи за критерієм відхилення значень від середньої величини на $1 / 2$ стандартного відхилення. Розрахунки проводились за методикою О. Сидоренко (Сидоренко, 2007: 20-23). До групи з середньою адаптивністю потрапили зимівники 3 показниками середнього загального рейтингу 7,0 - 5,2 балів, що складає відхилення значень від середньої величини (6,1 балів) 1/2 стандартного відхилення (стандартне відхилення дорівнює 1,88 балів, відповідно, 1/2 стандартного відхилення дорівнює 0,94$)$. Отож, у середню групу потрапив 21 зимівник, що складає 29,6\% від досліджуваної вибірки. До групи 3 високим і низьким рівнем адаптивності ввійшло по 25 осіб (по 35,2\%). Одержані дані подано в табл. 2.

Таблиия 2

Розподіл зимівників за рівнями адаптивності

\begin{tabular}{|l|c|c|c|}
\hline \multirow{2}{*}{$\begin{array}{c}\text { Групи зимівників та їх } \\
\text { рейтинг }\end{array}$} & високий & середній & низький \\
\cline { 2 - 4 } & $25(35,2 \%)$ & $21(29,6 \%)$ & $25(35,2 \%)$ \\
\hline Кількість осіб & $10,9-7,1$ & $7,0-5,2$ & $5,1-2,3$ \\
\hline $\begin{array}{l}\text { Середній загальний } \\
\text { рейтинг (у балах) }\end{array}$ & & & \\
\hline
\end{tabular}

Після цього ми припустили, що існує відмінність у наявності цінностей зимівників в різних за адаптивністю групах. Перевіримо це, об'єднавши цінності в 4 групи. Провівши дослідження за методикою М. Рокіча, ми розподілили виявлені у зимівників цінності так. Активне діяльне життя, цікава робота, продуктивне життя та впевненість у собі ми 
визначили як професійні цінності; життєва мудрість, пізнання, розвиток $i$ творчість - як пізнавальні цінності; суспільне визнання, свобода, щастя інших і наявність друзів - як соціальні цінності; здоров'я, матеріально забезпечене життя, щасливе сімейне життя, дозвілля - як матеріально-базові цінності. Далі проаналізували, як визначені цінності презентовані у ціннісномотиваційній сфері осіб з різним рівнем адаптивності. Результати подано в табл. 3.

Таблиия 3

Розподіл переважаючих цінностей у зимівників з різними рівнями адаптивності

\begin{tabular}{|c|c|c|c|c|}
\hline \multirow{2}{*}{$\begin{array}{c}\text { Рівні } \\
\text { адаптивності }\end{array}$} & \multicolumn{4}{|c|}{ цінності } \\
\cline { 2 - 5 } & професійні & пізнавальні & соціальні & $\begin{array}{c}\text { матеріально- } \\
\text { базові }\end{array}$ \\
\hline Високий & $9(36,0 \%)$ & $6(24,0 \%)$ & $8(32,0 \%)$ & $2(8,0 \%)$ \\
\hline Середній & $3(14,3 \%)$ & $10(47,6 \%)$ & $8(38,1 \%)$ & $0(0 \%)$ \\
\hline Низький & $1(4,0 \%)$ & $13(52,0 \%)$ & $3(12,0 \%)$ & $8(32,0 \%)$ \\
\hline
\end{tabular}

3 табл. 3 видно, що в групі зимівників із високим рівнем адаптивності переважають цінності професійного характеру (36,0\%). Це, зазвичай, люди старшого і середнього віку професіонал, що відбувся; вони знають, що хочуть від життя, марно не ризикують і мають досвід поведінки в екстремальних ситуаціях. Майже всі представники групи високої адаптації зимували в Антарктиці декілька разів.

В групі зимівників середнього і низького рівнів адаптивності переважають цінності пізнавального характеру (47,6\% і 52,0\% відповідно). Таких зимівників в роботі на далекому континенті приваблює незвична краса природи, пізнання нового, можливість займатися науковою роботою. Цікавим $є$ той факт, що у групі з низьким рівнем адаптивності значний відсоток мають цінності матеріального характеру - 32,0\%. Це стосується тих осіб (переважно, молодого віку), які від поїздки на роботу в Антарктиду очікують певного матеріального здобутку.

\section{Висновки}

Проблема вибору методів психологічної діагностики, прогнозування й корекції порушень у психологічній і психофізіологічній сфері осіб, що працюють в умовах Антарктики, полягає у необхідності визначення механізмів адаптації людини до впливу численних екстремальних факторів суворого клімату та психологічних особливостей зимівлі.

В статті презентовано аналіз наукових праць українських і зарубіжних учених щодо адаптації особистості до екстремальних умов, уточнено поняття «адаптація» та «адаптивність». Під поняттям «адаптація» ми розуміємо процес пристосування людини до змінених умов життєдіяльності, а щодо нашого дослідження - до екстремальних умов Антарктики. Поняття «адаптивність» ми розглядаємо як природну здатність людини до адаптації на фізіологічному рівні та, як набуту - на психологічному рівні. Загалом це здатність людини до адаптації, тобто ії пристосування до різних умов життєдіяльності.

Ціннісні орієнтації особистості розглянуто як принципи, якими вона керується у своїй діяльності. Встановлено особливості рейтингу термінальних цінностей українських зимівників.

Емпірично виокремлено 3 групи зимівників з різними рівнями адаптивності: високим, середнім і низьким. Критеріями для виокремлення стали: кількість зимівель; соціометричний 
рейтинг кожного окремого зимівника; наявність у зимівників важливих для життєдіяльності в екстремальних умовах Антарктики якостей особистості, визначених самими зимівниками. До першої п’ятірки якостей, які зимівники цінують в своїх товаришах, є такі: чесність; колективізм, товариськість; креативність, кмітливість; відповідальність; доброзичливість. Ці риси особистості, на думку зимівників, є необхідними для життєдіяльності в екстремальних умовах.

Доведено, що адаптація зимівників залежить певною мірою від особливостей ціннісно-мотиваційної сфери особистості. В осіб високого рівня адаптивності переважають професійні цінності, у осіб середнього та низького рівнів адаптивності - пізнавальні. Крім того, для осіб низького рівня адаптивності значну роль в мотивації до екстремальної діяльності відіграє матеріальна мотивація.

Перспективи подальших досліджень полягають у розробці типології особистості українського зимівника 3 урахуванням його індивідуально-типологічних особливостей, а саме, акцентуацій характеру, які сприяють або заважають адаптації до екстремальних умов життєдіяльності в Антарктиці.

\section{Література}

1. Гордєєв, А.Д. (2016). Розробка інформаційної технології процесу професійного відбору операторів екстремальних видів діяльності. Технологічний аудит та резерви виробництва, 5/1(31), 11-16.

2. Даниленко, Н.В. (2019). Теорія інстинктів В.І. Гарбузова як ресурс особистості. Матеріали III міжрегіон. наук.-практ. конф. (каталог психотехнологій; тези доп.) «Харківський осінній марафон психотехнологій» (м. Харків, 26 жовтня 2019 р.), (с. 99102). Харків : Діса плюс.

3. Ларссен, Е.Б. (2016). На пределе. Неделя без жалости к себе. Москва : Манн, Иванов и Фербер.

4. Маклаков, А.Г. (2017). Общая психология: учебное пособие для студентов вузов и слушателей курсов психологических дисииплин. Санкт-Петербург : Питер.

5. Мирошниченко, О.А. (2016). Роль темперамента зимовщика в процессе адаптации к условиям жизнедеятельности в Антарктике. Наука $i$ освіта. Психологія: наук.-практ. журнал, 7/СХХХVIII, 126-132.

6. Мірошниченко, О.А., Гуцуляк, О.П., $\quad \& \quad$ Марченко, О.В. $\quad$ (2018). Впровадження діагностичних процедур і тренінгових програм у психологічну підготовку та реабілітацію зимівників. Украӥнський антарктичний журнал, 16, 178-187.

7. Мірошниченко, О.А., \& Пасічник, І.Д. (2020). Готовність українських зимівників до життєдіяльності на антарктичній станції. Науковий часопис НПУ імені М.П. Драгоманова. Серія 12. Психологічні науки. 10(55), 58-67.

8. Моісеєнко, Є.В., Мірошниченко, О.А., Мадяр, С.А., Розова, К.В., Кузовик, В.Д., Ковалевська, О.Е., та ін. (2019). Технологї діагностики і прогнозу психофізіологічного статусу для відбору фахівиів до роботи в екстремальних умовах (методичні рекомендації). Київ : НТР «Антарктика».

9. Налчаджян, А.А. (2010). Психологическая адаптаџия: механизмы и стратегии. Москва : Эксмо.

10. Пишнов, Г.Ю. (2011). Підходи до оцінки ступеня вигоряння у осіб з напруженою працею за допомогою логістичних моделей. Український медичний часопис, 3, 101-105.

11. Райгородский, Д.Я. (2008). Практическая диагностика. Методики и тесты: учеб. пособие. Самара : «БАХРАХ-М».

12. Сидоренко, Е.В. (2007). Методы математической обработки в психологии. СанктПетербург : Речь.

13. Фресс, П., \& Пиаже, Ж. (1975). Экспериментальная психология. Москва : Прогресс.

14. Bakhmutova, L. (2019). Factors and models of interpersonal interaction of participants in longterm Ukrainian Antarctic Expeditions. Fundamental and applied researches in practice of leading scientific schools, 36(6), 48-55. 
15. Mehta, M., \& Chugh, G. (2011). Achievement Motivation and Adjustment in Members of Indian Scientific Expedition to Antarctica. Psychological Studies, 56(4), 404-409. https://doi.org/10.1007/s12646-011-0109-7

16. Moiseyenko, E., Sukhorukov, V., Pyshnov, G., Mankovska, I., Rozova, K., Miroshnichenko, O. et al. (2016). Antarctica challenges the new horizons in predictive, preventive, personalized medicine: preliminary results and attractive hypothesis for multidisciplinary prospective studies in the Ukrainian "Akademik Vernadsky" station. EPMA Journal, 7(1), 11. https://doi.org/10.1186/s13167-016-0060-8

\section{References}

1. Gordeev, A.D. (2016). Rozrobka informatsiynoyi tekhnolohiyi protsesu profesiynoho vidboru operatoriv ekstremalnykh vydiv diyalnosti [Development of information technology of the process of professional selection of operators of extreme activities]. Tekhnolohichnyy audyt ta rezervy vyrobnytstva - Technological audit and production reserves, 5/1(31), 11-16 [in Ukrainian].

2. Danilenko, N.V. (2019). Teoriya instynktiv V.I. Harbuzova yak resurs osobystosti [Theory of instincts V.I. Gorbuzkov as a person's life]. Proceedings from KhAMP' 19: Materialy III mizhrehion. nauk.-prakt. konf. (kataloh psykhotekhnolohiy; tezy dop.) "Kharkivskyy osinniy marafon psykhotekhnolohiy" - Materials III interregion. scientific-practical conf. (catalog of psychotechnologies; thesis add.) "Kharkiv Autumn Marathon Psychotechnologies" (Kharkiv, October 26, 2019), (pp. 99-102). Kharkiv : Disa Plus [in Ukrainian].

3. Larsen, E.B. (2016). Na predele. Nedelya bez zhalosti $k$ sebe [On Preved. Needlessly without tolerate to himself]. Moscow : Mann, Ivanov and Ferber [in Russian].

4. Maklakov, A.G. (2017). Obshchaya psikhologiya: uchebnoye posobiye dlya studentov vuzov $i$ slushateley kursov psikhologicheskikh distsiplin [General psychology: a textbook for university students and students of courses in psychological disciplines]. Saint Petersburg : Piter [in Russian].

5. Miroshnychenko, O.A. (2016). Rol temperamenta zimovshchika $\mathrm{v}$ protsesse adaptatsii $\mathrm{k}$ usloviiam zhiznedeiatelnosti $\mathrm{v}$ Antarktike [The role of the temperament of the winterer in the process of adaptation to the conditions of life in the Antarctic]. Nauka i osvita. Psykholohiya: nauk.-prakt. zhurnal - Science and Education. Psychology: Scientific and Practical Journal. 7/CXXKHVIII, 126-132 [in Russian].

6. Miroshnychenko, O.A., Hutsuliak, O.P., \& Marchenko, O.V. (2018). Vprovadzhennya diahnostychnykh protsedur i treninhovykh prohram $u$ psykholohichnu pidhotovku ta reabilitatsiyu zymivnykiv [Implementation of diagnostic procedures and training programs in the psychological preparation and rehabilitation of wintering grounds]. Ukrayinskyy antarktychnyy zhurnal - Ukrainian Antarctic Journal, 16, 178-187 [in Ukrainian].

7. Miroshnichenko, O.A., \& Pasichnyk, I.D. (2020). Hotovnist ukrayinskykh zymivnykiv do zhyttyediyalnosti na antarktychniy stantsiyi 「The readiness of Ukrainian winterers to life in an Antarctic station]. Naukovyy chasopys NPU imeni M.P. Drahomanova. Seriya 12. Psykholohichni nauky - Scientific Journal of National Pedagogical Dragomanov University. Series 12. Psychological Sciences, 10(55), 58-67 [in Ukrainian].

8. Moiseyenko, Ye.V., Miroshnychenko, O.A., Madyar, S.A., Rozova, K.V., Kuzovyk, V.D., Kovalevska, O.E., et al. (2019). Tekhnolohiyi diahnostyky i prohnozu psykhofiziolohichnoho statusu dlya vidboru fakhivtsiv do roboty $v$ ekstremalnykh umovakh (metodychni rekomendatsiyi) [Technologies for diagnosis and prognosis of psychophysiological status for the selection of specialists to work in extreme conditions (guidelines)]. Kyiv : NTR "Antarktyka" [in Ukrainian].

9. Nalchadzhian, A.A. (2010). Psikhologicheskaya adaptatsiya: mekhanizmy $i$ strategii [Psychological Adaptation: Mechanisms and Strategies]. Moscow : Eksmo [in Russian].

10. Pyshnov, G.Yu. (2011). Pidkhody do otsinky stupenya vyhoryannya u osib z napruzhenoyu pratseyu za dopomohoyu lohistychnykh modeley [Approaches to assess the degree of burnout in individuals with tense work with the help of logistic models]. Ukrayinskyy medychnyy chasopys - Ukrainian medical magazine, 3, 101-105 [in Ukrainian].

11. Rajgorodskij, D.Ja. (2008). Prakticheskaya diagnostika. Metodiki i testy: ucheb. Posobiye [Practical diagnostics. Procedures and tests]. Samara : "BAHRAH-M" [in Russian].

12. Sidorenko, E.V. (2007). Metody matematicheskoy obrabotki v psikhologii [Methods of mathematical care in psychology]. Saint Petersburg : Rech [in Russian]. 
13. Fress, P., \& Piaget, J. (1975). Eksperimentalnaya psikhologiya [Experimental psychology]. Moscow : Progress [in Russian].

14. Bakhmutova, L. (2019). Factors and models of interpersonal interaction of participants in longterm Ukrainian Antarctic Expeditions. Fundamental and applied researches in practice of leading scientific schools, 36(6), 48-55.

15. Mehta, M., \& Chugh, G. (2011). Achievement Motivation and Adjustment in Members of Indian Scientific Expedition to Antarctica. Psychological Studies, 56(4), 404-409. https://doi.org/10.1007/s12646-011-0109-7

16. Moiseyenko, E., Sukhorukov, V., Pyshnov, G., Mankovska, I., Rozova, K., Miroshnichenko, O. et al. (2016). Antarctica challenges the new horizons in predictive, preventive, personalized medicine: preliminary results and attractive hypothesis for multidisciplinary prospective studies in the Ukrainian "Akademik Vernadsky" station. EPMA Journal, 7(1), 11. https://doi.org/10.1186/s13167-016-0060-8

\title{
THE ROLE OF THE VALUE AND MOTIVATIONAL SPHERE OF PERSONALITY IN THE PROCESS OF ADAPTATION OF UKRAINIAN WINTERERS TO LIFE IN THE CONDITIONS OF ANTARCTICA
}

Olena Miroshnychenko

PhD in Pedagogy, Associate Professor, Associate Professor of the Department of Pedagogy, Professional Education and Management of Educational Institutions

Zhytomyr Ivan Franko State University

40,Velyka Berdychivska Str., Zhytomyr, Ukraine, 10008

perspektiva-z@ukr.net, http://orcid.org/0000-0002-5712-3752

\begin{abstract}
The article focuses on the study of the role of the value and motivational sphere of the personality of Ukrainian winterers in the process of adaptation to life at the Ukrainian Antarctic station "Academician Vernadsky". The actuality of the research chosen is based on the fact that Ukraine is one of 19 countries in the world with permanent Antarctic stations. The participants of Ukrainian Antarctic Expeditions fulfill scientific research on such branches of sciences as biology, hydrometeorology, geophysics, geology, engineering, psychology, psychophysiology. Winterers have to work in extreme conditions dealing with exposure to low temperatures, jet lag and light zones, sensory deprivation, psychological characteristics of work and rest in a limited team. The purpose of this article is the theoretical substantiation and empirical proof of the role of the value and motivational sphere of personality in the process of adapting Ukrainian winterers to life in the conditions of Antarctica. The scientific studies of domestic and foreign researchers who deal with the problem of adaptation to life in extreme conditions are analyzed. The concept of adaptation and adaptability to extreme conditions is specified. Methodological tools of research are approved and described. An empirical study on separating the groups of high, medium and low adaptability to vital activity in the extreme conditions of Antarctica is conducted. The criteria for allocating the groups of different levels of adaptability are determined: the number of winterers, sociometric rating, the presence of personality qualities that are essential for life in extreme conditions. The role of value and motivational sphere among the representatives of each group is determined.

It is proved that the winterers who have a high level of adaptability to a greater extent have professional values; the winterers who have an average and low level of adaptability have cognitive values; in addition to this the winterers who have a low level of adaptability to a large extent have material values.
\end{abstract}

Keywords: adaptation, adaptability, personality values, groups of high, medium and low adaptability, distribution of sampling into groups, personality, life, value-motivational sphere. 